九州大学学術情報リポジトリ

Kyushu University Institutional Repository

\title{
Analyses of Sporads Types at Different Bud Development Stages of Phalaenopsis Orchids
}

Hsu, Shan-Te

Department of Horticultural Science, National Chiayi University

Wongprichachan, Prapassorn

Department of Horticultural Science, National Chiayi University

Chou, Yi-Mei

Department of Horticultural Science, National Chiayi University

Liu, Tzu-Yu

Department of Horticultural Science, National Chiayi University

他

https://doi.org/10.5109/1434378

出版情報：九州大学大学院農学研究院紀要. 59 (1)，pp. 39-44，2014-02-28. Faculty of Agriculture， Kyushu University

バージョン:

権利関係: 


\title{
Analyses of Sporads Types at Different Bud Development Stages of Phalaenopsis Orchids
}

\author{
Shan-Te HSU ${ }^{1}$, Prapassorn WONGPRICHACHAN ${ }^{1}$, Yi-Mei CHOU ${ }^{1}$, \\ Tzu-Yu LIU ${ }^{1}$, Ikuo MIYAJIMA ${ }^{2}$ and Kuang-Liang HUANG ${ }^{1 *}$ \\ Institute of Tropical Agriculture, Kyushu University, Fukuoka 812-8581, Japan \\ (Received October 28, 2013 and accepted November 11, 2013)
}

\begin{abstract}
This study aimed to investigate sporad types of pollinia collected from flower buds at different development stages to determine the optimal timing for unreduced male gamete induction. Pollinia collected at different flower development stages in 6 Phalaenopsis species, including P. amabilis, P. amboinensis var. flava, P. equestris, P. hieroglyphica, P. venosa and P. violacea, were used to examine the distribution of sporad types. The results showed that the highest percentages of monad were observed when the sizes of flower buds were about or less than $5 \mathrm{~mm}$ in $P$. amabilis, $P$. equestris, . hieroglyphica and $P$. venosa, and about or less than $7.5 \mathrm{~mm}$ in $P$. amboinensis var. flava and $P$. violacea. Accordingly, those sized flower buds might be suitable for subsequent unreduced male gamete induction needed for developing an efficient sexual polyploidization breeding scheme in Phalaenopsis.
\end{abstract}

Key words: flower bud, monad, pollinium

\section{INTRODUCTION}

Phalaenopsis orchid has been a favorite consumer product due to its attractive color, graceful and longlasting flowers. It is commonly recognized that Phalaenopsis orchid is economically the most important mass-marketed potted-plant orchid. Polyploid cultivars of Phalaenopsis have superior horticultural traits such as larger size of the flowers and better shape. The Phalaenopsis cultivars used for breeding are usually divided into two groups including the standard big flower group such as derivatives of $P$. amabilis and $P$. schilleriana, the novelty group such as descendants of $P$. violacea, $P$. amboinensis and $P$. venosa (Tang and Chen, 2007).

Polyploid has played an important role in the improvement of many plant species and hybrids. The field of floriculture has probably benefited the most because first one polyploidy can increase genetic variability, and second polyploidy tends to increase the size and substance and improve the form of flowers. Because of these characteristics, breeders have unconsciously selected and used polyploid forms as parents (Grlesbach, 1985).

Sexual polyploidy in plant breeding, $2 n$ gametes (including $2 n$ pollen and $2 n$ eggs) play an important role (Ramanna and Jacobsen, 2003), can overcome the barriers to hybridization, or enable future generations to restore. Suitable flower bud before treatment flower bud with antimicrotubule agent reported in many crops such as lily, begonia and tulip (Akutsu et al., 2007; Barba-Gonzalez et al., 2006; Dewitte et al., 2010).

\footnotetext{
1 Department of Horticultural Science, National Chiayi University, Chiayi City, Taiwan, Republic of China

2 Institute of Tropical Agriculture, Kyushu University, Fukuoka 812-8581, Japan

* Corresponding author (Email: klhuang@mail.ncyu.edu.tw)
}

Akutsu et al. (2007) showed that effects were optimal when treatments started during pollen mother cell progression to metaphase I. In tulip microsporogenesis occurs inside the bulb, in genera where microsporogenesis starts within visible flower buds, antimicrotubule agent starts within visible flower buds (Dewitte et al., 2010).

This study aimed to determine which flower bud length of Phalaenopsis that suitable for use to induction of male unreduced gamete production for developing an efficient sexual polyploidization breeding scheme in Phalaenopsis.

\section{MATERIALS AND METHODS}

\section{Plant materials}

Six Phalaenopsis species $(2 \mathrm{n}=2 \mathrm{x}=38)$, including P. amabilis, $P$. amboinensis var. flava, $P$. equestris, $P$. hieroglyphica, $P$. venosa and $P$. violacea, were used in this experiment (Fig. 1). Plants were cultivated in $10 \mathrm{~cm}$ diameter pots in a greenhouse at the Horticultural Technology Center, National Chiayi University, Chiayi City, Taiwan (R.O.C.).

\section{Observation of sporad types at different flower bud development stages in Phalaenopsis orchids}

To quantify the number of different types of sporads in Phalaenopsis, pollinia were stained with lactophenol-acid fuchsin solution (Lim et al., 2001). Pollinia from different sized flower buds were fixed with 95\% ethanol-glacial acetic acid (3:1 v/v) solution for 24 hours, hydrolyzed in $1 \mathrm{~N} \mathrm{HCl}$ for 20 minutes at $60^{\circ} \mathrm{C}$, rinsed three times with distilled water, and stained with lactophenol-acid fuchsin solution containing $50 \mathrm{mg}$ acid fuchsin, $5 \mathrm{~g}$ phenol, $5 \mathrm{~mL}$ lactic acid, $25 \mathrm{~mL}$ glycerol, $10 \mathrm{~mL}$ 95\% ethanol, and $60 \mathrm{~mL}$ distilled water (Lim et al., 2001). Materials for observation were examined under microscope (Axio version Rel.4.5, 


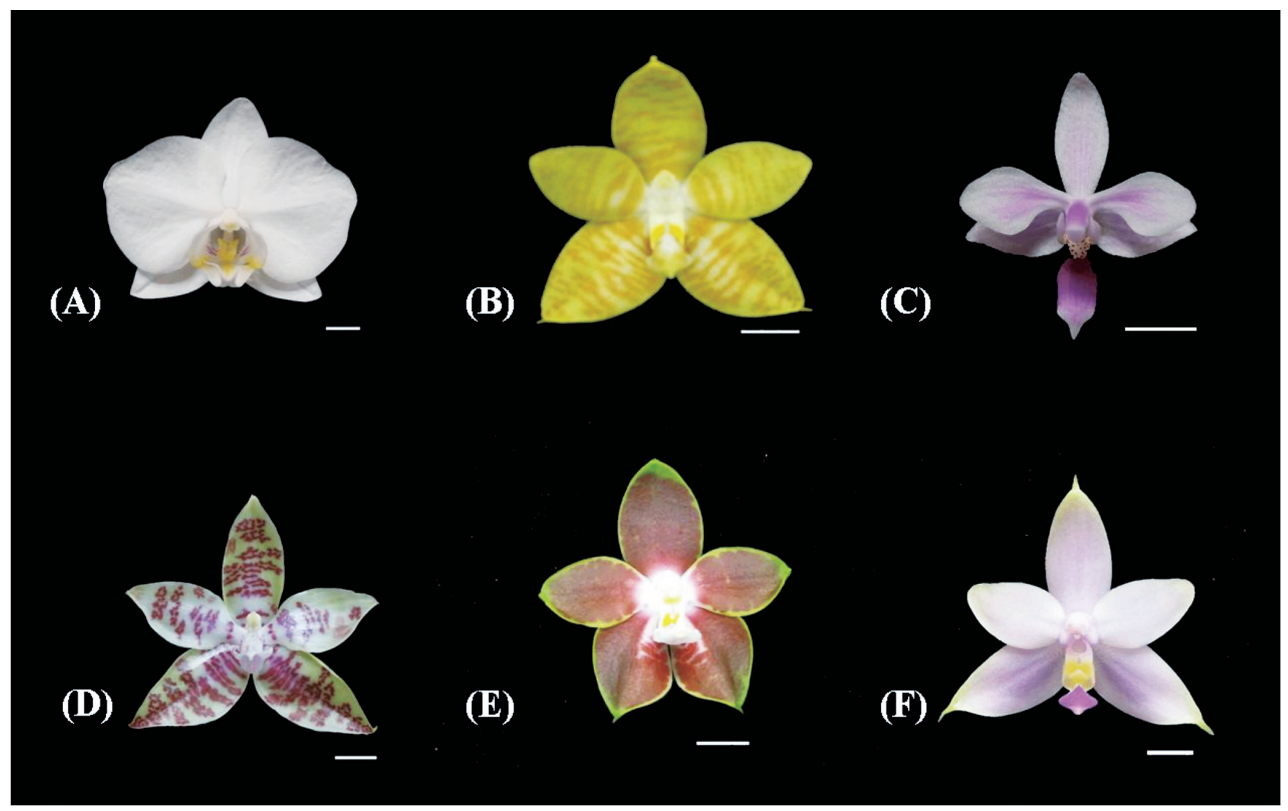

Fig. 1. Flower of plant materials: (A) Phalaenopsis amabilis; (B) P. amboinensis var. flava; (C) P. equestris; (D) P. hieroglyphica; (E) P. venosa and (F) P. violacea. Bar $=1 \mathrm{~cm}$.
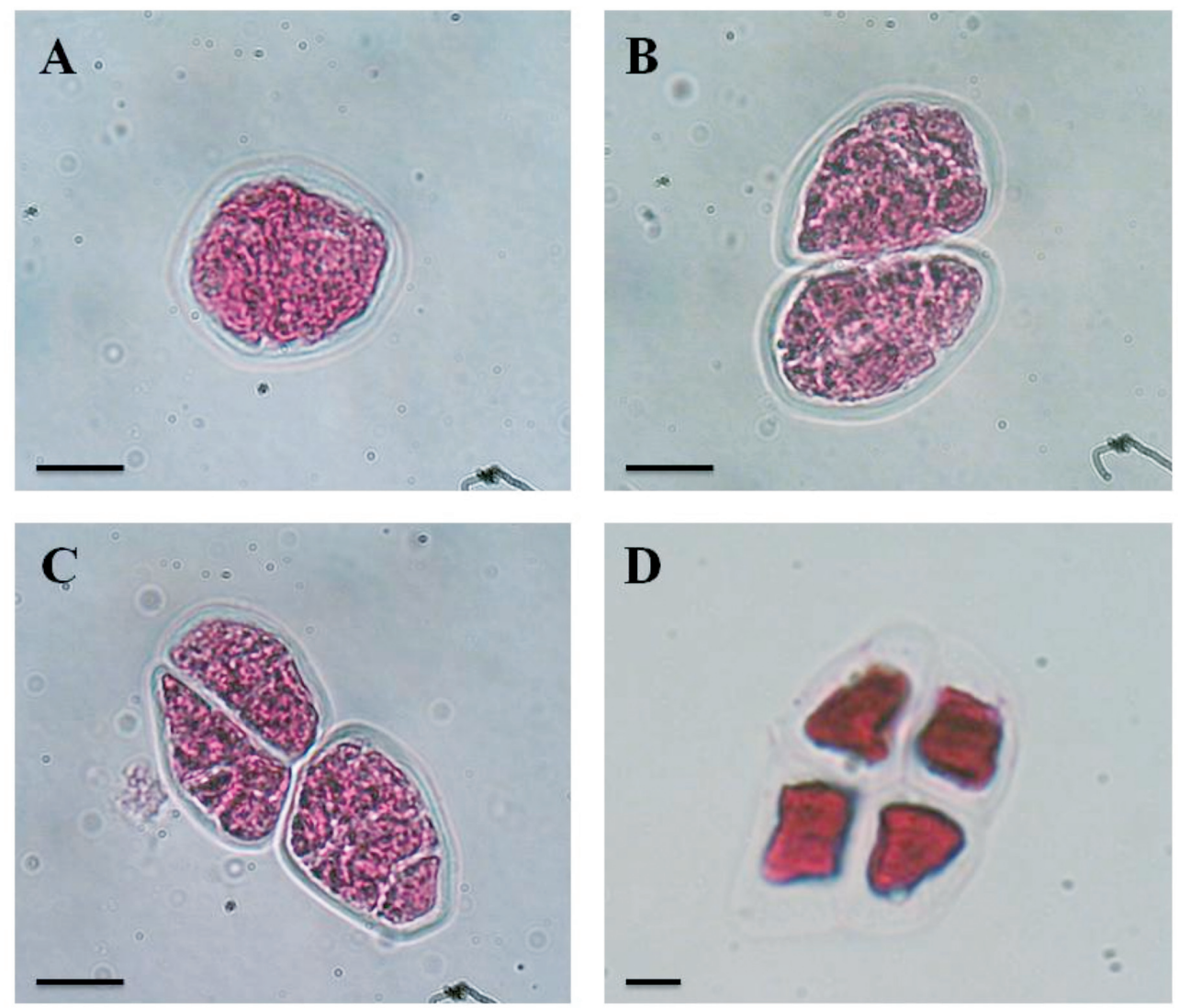

Fig. 2. Lactophenol-acid fuchsin staining of sporads in Phalaenopsis. (A) Monad, (B) Dyad, (C) Triad, (D) Tetrad. Bar $=5 \mu \mathrm{m}$.

Germany) with a CCD camera (Cannon A620, Japan). One thousand sporads were categorized according to the sporad types, and at least three different plants were used for examination. Pictures were also taken using a digital camera (Cannon A620, Japan). Sporad types were classified as monad, dyad, triad, tetrad according to the number of nuclei presented (1 to 4 nuclei) respectively (Fig. 2).

\section{RESULTS}

The sporad types of pollinia collected from flower 
buds at different development stages of 6 species Phalaenopsis were observed. Samples of pollinia from different flower bud size of $P$. amabilis, P. equestris, P. hieroglyphica, P. amboinensis var. flava, P. venosa and $P$. violacea were stained with lactophenol-acid fuchsin to quantify the different sporad types at least for one thousand sporads. Sporad types were classified as monad, dyad, triad, tetrad according to the number of nuclei presented within the structure (Fig. 2).

\section{Sporad types of $\boldsymbol{P}$. amabilis}

Results from sporad observations in P. amabilis showed that sporad types of pollinia divided into $75.2 \%$ of monad and $24.8 \%$ of dyad at flower bud size of $5.0 \pm$ $0.5 \mathrm{~mm}, 10.5 \%$ of monad, $87.8 \%$ of dyad and $1.7 \%$ of tetrad at flower bud size of $7.5 \pm 0.5 \mathrm{~mm}$, less than $2 \%$ of dyad and 98.2-98.8\% of tetrad at flower bud sizes of $10.0 \pm 0.5 \mathrm{~mm}$ and $12.5 \pm 0.5 \mathrm{~mm}$, and $100 \%$ of tetrad at flower bud sizes bigger than $15.0 \pm 0.5 \mathrm{~mm}$ to flower fully open (Table 1, Fig. 3A).

\section{Sporad types of $\boldsymbol{P}$. amboinensis var. flava}

Results from sporad observations in P. amboinensis var. flava showed that sporad types of pollinia divided into $98.5 \%$ of monad and $1.5 \%$ of dyad at flower bud size of $7.5 \pm 0.5 \mathrm{~mm}, 39.3 \%$ of monad, $58.8 \%$ of dyad, $0.3 \%$ of triad and $1.6 \%$ of tetrad at flower bud size of $10.0 \pm 0.5 \mathrm{~mm}, 31.5 \%$ of monad, $59.3 \%$ of dyad, $0.6 \%$ of triad and $8.6 \%$ of tetrad at flower bud size of $12.5 \pm$ $0.5 \mathrm{~mm}, 6.1 \%$ of monad, $35.2 \%$ of dyad, $0.5 \%$ of triad and $58.2 \%$ of tetrad at flower bud size of $15.0 \pm 0.5 \mathrm{~mm}$, In addition, flower bud size bigger than $20.0 \pm 0.5 \mathrm{~mm}$ to flower fully open showed tetrad reach to $99.3-99.6 \%$ and triad $0.5-0.7 \%$ (Table 2, Fig. 3B).

\section{Sporad types of $P$. equestris}

Results from sporad observations in P. equestris showed that sporad types of pollinia divided into $90.7 \%$

Table 1. Distribution of sporad types of pollinia collected from flower buds at development stages in Phalaenopsis amabilis

\begin{tabular}{|c|c|c|c|c|c|c|c|c|c|}
\hline \multirow{3}{*}{$\begin{array}{c}\begin{array}{c}\text { Flower bud length } \\
(\mathrm{mm})\end{array} \\
5.0 \pm 0.5\end{array}$} & \multirow{3}{*}{$\begin{array}{c}\begin{array}{c}\text { Total number of } \\
\text { sporads observed }\end{array} \\
1213\end{array}$} & \multicolumn{8}{|c|}{ Number (percentage) of the various sporad types } \\
\hline & & \multicolumn{2}{|c|}{ Monad } & \multicolumn{2}{|c|}{ Dyad } & \multicolumn{2}{|c|}{ Triad } & \multicolumn{2}{|c|}{ Tetrad } \\
\hline & & 912 & $(75.2)$ & 301 & $(24.8)$ & 0 & $(0)$ & 0 & $(0)$ \\
\hline $7.5 \pm 0.5$ & 1273 & 135 & $(10.5)$ & 1117 & $(87.8)$ & 0 & $(0)$ & 21 & (1.7) \\
\hline $10.0 \pm 0.5$ & 1100 & 0 & $(0)$ & 20 & $(1.8)$ & 0 & $(0)$ & 1080 & $(98.2)$ \\
\hline $12.5 \pm 0.5$ & 1260 & 0 & $(0)$ & 15 & $(1.2)$ & 0 & $(0)$ & 1245 & (98.8) \\
\hline $15.0 \pm 0.5$ & 1080 & 0 & $(0)$ & 0 & $(0)$ & 0 & $(0)$ & 1080 & (100) \\
\hline $17.5 \pm 0.5$ & 1016 & 0 & (0) & 0 & (0) & 0 & (0) & 1016 & (100) \\
\hline Blooming & 1012 & 0 & (0) & 0 & $(0)$ & 0 & (0) & 1012 & (100) \\
\hline
\end{tabular}

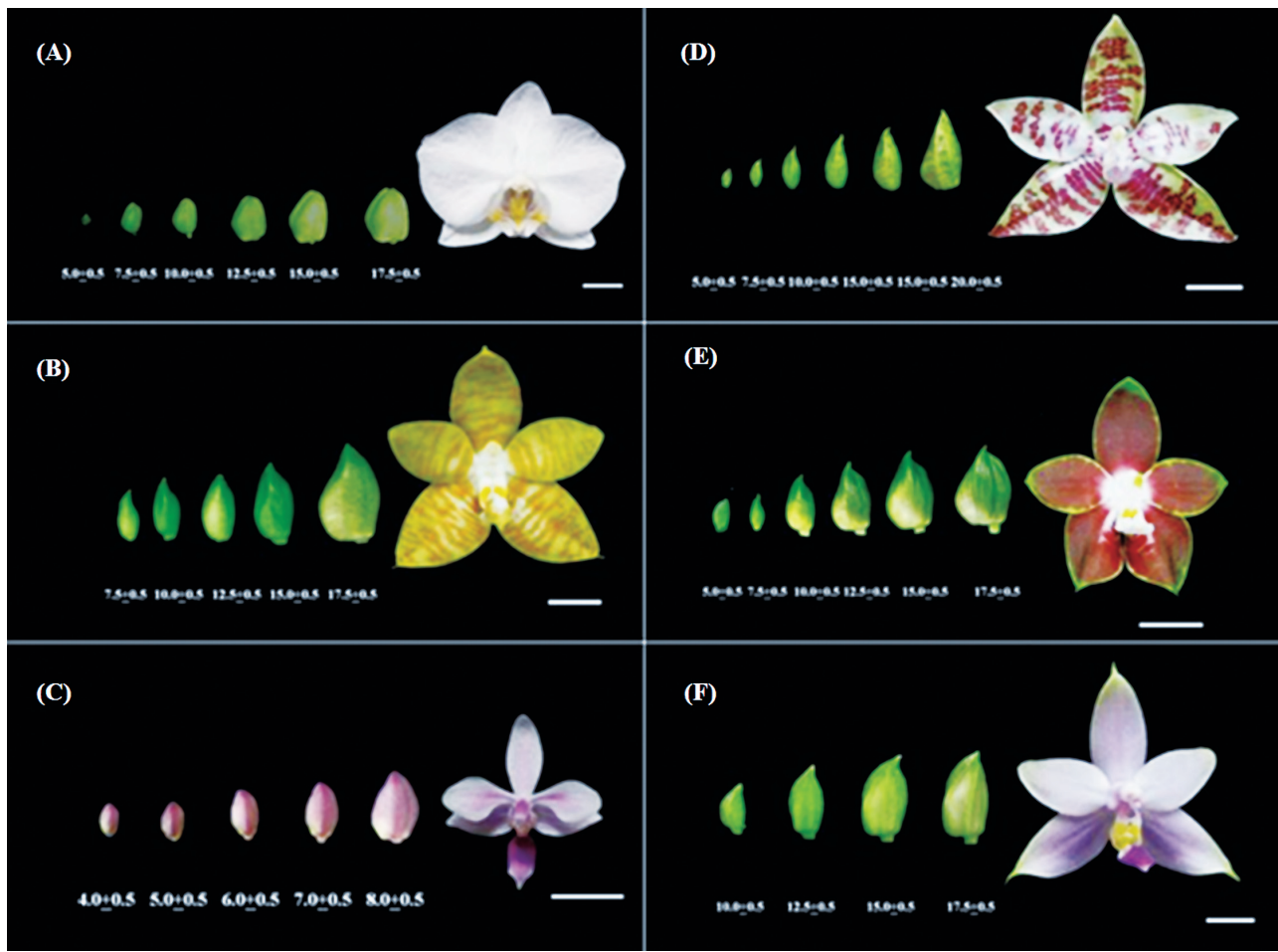

Fig. 3. Flower buds at different development stages of 6 species Phalaenopsis

(A) P. amabilis; (B) P. amboinensis var. flava; (C) P. equestris; (D) P. hieroglyphica; (E) P. venosa and (F) P. violacea. Bar=1 cm. 
Table 2. Distribution of sporad types of pollinia collected from flower buds at development stages in Phalaenopsis amboinensis var. flava

\begin{tabular}{|c|c|c|c|c|c|c|c|c|c|}
\hline \multirow{3}{*}{$\begin{array}{c}\begin{array}{c}\text { Flower bud length } \\
(\mathrm{mm})\end{array} \\
7.5 \pm 0.5\end{array}$} & \multirow{3}{*}{$\begin{array}{c}\begin{array}{c}\text { Total number of } \\
\text { sporads observed }\end{array} \\
1033\end{array}$} & \multicolumn{8}{|c|}{ Number (percentage) of the various sporad types } \\
\hline & & \multicolumn{2}{|c|}{ Monad } & \multicolumn{2}{|c|}{ Dyad } & \multicolumn{2}{|c|}{ Triad } & \multicolumn{2}{|c|}{ Tetrad } \\
\hline & & 1017 & $(98.5)$ & 16 & $(1.5)$ & 0 & $(0)$ & 0 & $(0)$ \\
\hline $10.0 \pm 0.5$ & 1002 & 394 & $(39.3)$ & 589 & $(58.8)$ & 3 & $(0.3)$ & 16 & (1.6) \\
\hline $12.5 \pm 0.5$ & 1081 & 340 & $(31.5)$ & 642 & $(59.3)$ & 6 & $(0.6)$ & 93 & (8.6) \\
\hline $15.0 \pm 0.5$ & 1018 & 62 & $(6.1)$ & 38 & $(35.2)$ & 6 & $(0.5)$ & 592 & $(58.2)$ \\
\hline $20.0 \pm 0.5$ & 1084 & 0 & $(0)$ & 0 & (0) & 7 & $(0.5)$ & 1077 & (99.6) \\
\hline Blooming & 1066 & 0 & $(0)$ & 0 & $(0)$ & 7 & $(0.7)$ & 1059 & (99.3) \\
\hline
\end{tabular}

Table 3. Distribution of sporad types of pollinia collected from flower buds at development stages in Phalaenopsis equestris

\begin{tabular}{cccccccccc}
\hline \multirow{2}{*}{$\begin{array}{c}\text { Flower bud length } \\
(\mathrm{mm})\end{array}$} & $\begin{array}{c}\text { Total number of } \\
\text { sporads observed }\end{array}$ & \multicolumn{8}{c}{ Number (percentage) of the various sporad types } \\
\cline { 3 - 11 } & \multicolumn{2}{c}{ Monad } & \multicolumn{2}{c}{ Dyad } & \multicolumn{2}{c}{ Triad } & Tetrad \\
\hline $4.0 \pm 0.5$ & 1035 & 939 & $(90.7)$ & 96 & $(9.3)$ & 0 & $(0)$ & 0 & $(0)$ \\
$5.0 \pm 0.5$ & 1320 & 963 & $(73.0)$ & 357 & $(27.0)$ & 0 & $(0)$ & 0 & $(0)$ \\
$6.0 \pm 0.5$ & 1016 & 80 & $(7.9)$ & 928 & $(91.3)$ & 8 & $(0.8)$ & 0 & $(0)$ \\
$7.0 \pm 0.5$ & 1640 & 0 & $(0)$ & 464 & $(28.3)$ & 64 & $(3.9)$ & 1112 & $(67.8)$ \\
$8.0 \pm 0.5$ & 1112 & 0 & $(0)$ & 8 & $(0.7)$ & 72 & $(6.5)$ & 1032 & $(92.8)$ \\
Blooming & 1010 & 0 & $(0)$ & 0 & $(0.0)$ & 50 & $(5.0)$ & 960 & $(95.0)$ \\
\hline
\end{tabular}

Table 4. Distribution of sporad types of pollinia collected from flower buds at development stages in Phalaenopsis hieroglyphica

\begin{tabular}{ccrrrrrrrrr}
\hline \multirow{2}{*}{$\begin{array}{c}\text { Flower bud length } \\
(\mathrm{mm})\end{array}$} & $\begin{array}{c}\text { Total number of } \\
\text { sporads observed }\end{array}$ & \multicolumn{8}{c}{ Mumber (percentage) of the various sporad types } \\
\cline { 3 - 11 } & \multicolumn{2}{c}{ Monad } & \multicolumn{2}{c}{ Dyad } & \multicolumn{3}{c}{ Triad } & \multicolumn{2}{c}{ Tetrad } \\
\hline $5.0 \pm 0.5$ & 1179 & 1056 & $(89.6)$ & 123 & $(10.4)$ & 0 & $(0)$ & 0 & $(0)$ \\
$7.5 \pm 0.5$ & 1072 & 581 & $(54.2)$ & 469 & $(43.8)$ & 22 & $(2.0)$ & 0 & $(0)$ \\
$10.0 \pm 0.5$ & 1149 & 512 & $(44.6)$ & 496 & $(43.2)$ & 18 & $(1.5)$ & 123 & $(10.7)$ \\
$15.0 \pm 0.5$ & 1120 & 180 & $(16.1)$ & 822 & $(73.4)$ & 16 & $(1.4)$ & 102 & $(9.1)$ \\
$17.5 \pm 0.5$ & 1332 & 36 & $(2.7)$ & 100 & $(7.5)$ & 17 & $(1.3)$ & 1179 & $(88.5)$ \\
$20.0 \pm 0.5$ & 1112 & 0 & $(0)$ & 0 & $(0)$ & 15 & $(1.3)$ & 1097 & $(98.7)$ \\
Blooming & 1050 & 0 & $(0)$ & 0 & $(0)$ & 13 & $(1.2)$ & 1037 & $(98.8)$ \\
\hline
\end{tabular}

Table5. Distribution of sporad types of pollinia collected from flower buds at development stages in Phalaenopsis venosa

\begin{tabular}{ccrrrrrrrr}
\hline \multirow{2}{*}{$\begin{array}{c}\text { Flower bud length } \\
(\mathrm{mm})\end{array}$} & $\begin{array}{c}\text { Total number of } \\
\text { sporads observed }\end{array}$ & \multicolumn{7}{c}{ Number (percentage) of the various sporad types } \\
\cline { 3 - 10 } & \multicolumn{2}{c}{ Monad } & \multicolumn{2}{c}{ Dyad } & \multicolumn{2}{c}{ Triad } & \multicolumn{2}{c}{ Tetrad } \\
\hline $5.0 \pm 0.5$ & 1186 & 784 & $(66.1)$ & 400 & $(33.7)$ & 0 & $(0)$ & 2 & $(0.2)$ \\
$7.5 \pm 0.5$ & 1096 & 92 & $(8.4)$ & 463 & $(42.2)$ & 0 & $(0)$ & 541 & $(49.4)$ \\
$10.0 \pm 0.5$ & 1081 & 43 & $(4.0)$ & 103 & $(9.5)$ & 0 & $(0)$ & 935 & $(86.5)$ \\
$12.5 \pm 0.5$ & 1024 & 0 & $(0)$ & 20 & $(2.0)$ & 0 & $(0)$ & 1004 & $(98.0)$ \\
$15.0 \pm 0.5$ & 1053 & 0 & $(0)$ & 13 & $(1.2)$ & 0 & $(0)$ & 1040 & $(98.8)$ \\
$15.5 \pm 0.5$ & 1025 & 0 & $(0)$ & 0 & $(0)$ & 0 & $(0)$ & 1025 & $(100)$ \\
Blooming & 1188 & 0 & $(0)$ & 0 & $(0)$ & 0 & $(0)$ & 1118 & $(100)$ \\
\hline
\end{tabular}


Table 6. Distribution of sporad types of pollinia collected from flower buds at development stages in Phalaenopsis violacea

\begin{tabular}{|c|c|c|c|c|c|c|c|c|c|}
\hline \multirow{3}{*}{$\begin{array}{l}\begin{array}{l}\text { Flower bud length } \\
(\mathrm{mm})\end{array} \\
7.5 \pm 0.5\end{array}$} & \multirow{3}{*}{$\begin{array}{c}\begin{array}{c}\text { Total number of } \\
\text { sporads observed }\end{array} \\
1141\end{array}$} & \multicolumn{8}{|c|}{ Number (percentage) of the various sporad types } \\
\hline & & \multicolumn{2}{|c|}{ Monad } & \multicolumn{2}{|c|}{ Dyad } & \multicolumn{2}{|c|}{ Triad } & \multicolumn{2}{|c|}{ Tetrad } \\
\hline & & 930 & $(81.5)$ & 211 & $(18.5)$ & 0 & $(0)$ & 0 & $(0.0)$ \\
\hline $10.0 \pm 0.5$ & 1018 & 200 & $(19.6)$ & 818 & $(80.4)$ & 0 & $(0)$ & 0 & $(0.0)$ \\
\hline $12.5 \pm 0.5$ & 1063 & 0 & $(0)$ & 120 & $(11.3)$ & 0 & $(0)$ & 943 & $(88.7)$ \\
\hline Blooming & 1105 & 0 & (0) & 0 & $(0.0)$ & 0 & $(0)$ & 1105 & (100) \\
\hline
\end{tabular}

of monad and $9.3 \%$ of dyad at flower bud size of $4.0 \pm 0.5 \mathrm{~mm}, 73.0 \%$ of monad and $27.0 \%$ of dyad at flower bud size of $5.0 \pm 0.5 \mathrm{~mm}, 7.9 \%$ of monad, $91.3 \%$ of dyad and $0.8 \%$ of triad at flower bud size of $6.0 \pm 0.5 \mathrm{~mm}$, $28.3 \%$ of dyad, $3.9 \%$ of triad and $67.8 \%$ of tetrad at flower bud size of $7.0 \pm 0.5 \mathrm{~mm}, 0.7 \%$ of dyad, $6.5 \%$ of triad and $92.8 \%$ of tetrad at flower bud size of $8.0 \pm$ $0.5 \mathrm{~mm}$, In addition, flower fully open showed $5 \%$ of triad and $95 \%$ of tetrad (Table 3, Fig. 3C).

\section{Sporad types of $\boldsymbol{P}$. hieroglyphica}

Results from sporad observations in P. hieroglyphica showed that sporad types of pollinia divided into $89.6 \%$ of monad and $10.4 \%$ of dyad at flower bud size of $5.0 \pm 0.5 \mathrm{~mm}, 54.2 \%$ of monad, $43.8 \%$ of dyad and $2.0 \%$ of triad at flower bud size of $7.5 \pm 0.5 \mathrm{~mm}, 44.6 \%$ of monad, $43.2 \%$ of dyad, $1.5 \%$ of triad and $10.7 \%$ of tetrad at flower bud size of $10.0 \pm 0.5 \mathrm{~mm}, 16.1 \%$ of monad, $73.4 \%$ of dyad, $1.4 \%$ of triad and $9.1 \%$ of tetrad at flower bud size of $15.0 \pm 0.5 \mathrm{~mm}, 2.7 \%$ of monad, $7.5 \%$ of dyad, $1.3 \%$ of triad and $88.5 \%$ of tetrad at flower bud size of $17.5 \pm 0.5 \mathrm{~mm}, 1.3 \%$ of triad and $98.7 \%$ of tetrad at flower bud size of $20.0 \pm 0.5 \mathrm{~mm}$, In addition, flower fully open showed $1.2 \%$ of triad and $98.8 \%$ of tetrad (Table 4 , Fig. 3D).

\section{Sporad types of in $P$. venosa}

Results from sporad observations in $P$. venosa showed that sporad types of pollinia divided into $66.1 \%$ of monad, $33.7 \%$ of dyad and $0.2 \%$ of tetrad at flower bud size of $5.0 \pm 0.5 \mathrm{~mm}, 8.4 \%$ of monad, $42.2 \%$ of dyad and $49.4 \%$ of tetrad at flower bud size of $7.5 \pm 0.5 \mathrm{~mm}$, $4.0 \%$ of monad, $9.5 \%$ of dyad and $86.5 \%$ of tetrad at flower bud size of $10.0 \pm 0.5 \mathrm{~mm}, 2.0 \%$ of dyad and $98.0 \%$ of tetrad at flower bud size of $12.5 \pm 0.5 \mathrm{~mm}, 1.2 \%$ of dyad and $98.8 \%$ of tetrad at flower bud size of $15.0 \pm 0.5 \mathrm{~mm}, 100 \%$ of tetrad at flower bud sizes of 15.5 $\pm 0.5 \mathrm{~mm}$ to flower fully open (Table 5, Fig. 3E).

\section{Sporad types of $\boldsymbol{P}$. violacea}

Results from sporad observations in $P$. violacea showed that sporad types of pollinia divided into $81.5 \%$ of monad and $18.5 \%$ of dyad at flower bud size of $7.5 \pm$ $0.5 \mathrm{~mm}, 19.6 \%$ of monad and $80.4 \%$ of dyad at flower bud size of $10.0 \pm 0.5 \mathrm{~mm}, 11.3 \%$ of dyad and $88.7 \%$ of tetrad at flower bud size of $12.5 \pm 0.5 \mathrm{~mm}, 100 \%$ of tet$\mathrm{rad}$ at flower bud sizes of $15.0 \pm 0.5 \mathrm{~mm}$ to flower fully open (Table 6, Fig. 3F).

\section{DISCUSSION}

This study aimed to evaluate the optimal timing for unreduced male gamete induction based on the observation of sporad types of pollinia collected at different flower bud development stages in Phalaenopsis orchids. Using the immature flower buds with suitable sizes treated with chemical (Dewitte et al., 2010; Li et al., 2008; Wu et al., 2007; Xiao et al., 2007; Zhong et al., 2010) or physical methods (Akutsu et al., 2007; BarbaGonzales et al., 2006; Kitamura et al., 2009; Okazaki et al., 2005; Sato et al., 2010) to facilitate the successful induction of 2 gametes is an important strategy. Akutsu et al. (2007) reported lily bud length could be used to judge the microspore mother cell division for unreduced male gamete induction, and a few $2 n$ pollen grains were induced by nitrous oxide $\left(\mathrm{N}_{2} \mathrm{O}\right)$ treatment using plants with anthers in prophase I, whereas mixed pollen grains of differing size were produced using plants undergoing meiotic metaphase predominantly in anthers. In similar idea, we tried to analyze the relationship between bud size and meiotic stage in Phalaenopsis orchids. However we just simply observed sporad types of pollinia instead of detailed, labor-consuming and timecosting examination of microspore mother cell progression. In addition, percentage of tetrads also can use as a determination for selecting pollen donor plant in Phalaenopsis breeding (Bolaños-Villegas et al., 2008; Chou, 2013; Wongprichachan et al., 2012).

Our results showed that distributions of sporad types of pollinia collected from flower buds at development stages varied among six Phalaenopsis species studied in this experiment. The highest percentages of monad were observed when the sizes of flower buds were about or less than $5.0 \mathrm{~mm}$ in $P$. amabilis, P. equestris, $P$. hieroglyphica and $P$. venosa, and about or less than $7.5 \mathrm{~mm}$ in $P$. amboinensis var. flava and $P$. violacea (Table 1-6). The results were also similar with those of Chou (2013)'s study. We have previously shown that $\mathrm{N}_{2} \mathrm{O}$ treatment with flower buds sized about 4.5-5.0 mm is an effective method to induce unreduced gamete (Wongprichachan et al., 2013a) and polyploid (Wongprichachan et al., 2013b) in P. amabilis.

Since the distribution of sporad types of pollinia collected from flower buds sized about $5.0 \mathrm{~mm}$ was $75.2 \%$ of monad and $24.8 \%$ of dyad, and those about $7.5 \mathrm{~mm}$ was $10.5 \%$ of monad, $87.8 \%$ of dyad and $1.7 \%$ of tetrad (Table 1) in P. amabilis. Therefore most of pol- 
len mother cells (PMCs) at flower bud development stages ranged from 5.0 to $7.5 \mathrm{~mm}$ in size must be undergoing meiosis and major PMCs at the stage of flower buds sized about $5.0 \mathrm{~mm}$ must be before meiosis II in meiotic progression. The results were similar with those of Akutsu et al. (2007)'s report that putative 2n pollen grains were formed by treating PMCs in metaphase I to metaphase II and the $\mathrm{N}_{2} \mathrm{O}$ treatment was most effective in obtaining $2 \mathrm{n}$ pollen when administered during metaphase I in lilies. Accordingly, establishing relationship between bud size and meiotic stage through simply sporad observation might be a useful strategy for unreduced male gamete induction needed for developing an efficient sexual polyploidization breeding scheme in Phalaenopsis.

\section{REFERENCES}

Akutsu, M., S. Kitamura, R. Toda, I. Miyajima and K. Okazaki. 2007 Production of $2 n$ pollen of Asiatic hybrid lilies by nitrous oxide treatment. Euphytica 155: 143-152

Barba-Gonzalez, R., C.T. Miller, M. S. Ramanna and J. M. Van Tuyl. 2006 Nitrous oxide $\left(\mathrm{N}_{2} \mathrm{O}\right)$ induces $2 n$ gametes in sterile $\mathrm{F} 1$ hybrids between Oriental $\times$ Asiatic lily (Lilium) hybrids and leads to intergenomic recombination. Euphytica 148: 303-309

Bolaños-Villegas, P., S. W. Chin and F. C. Chen. 2008 Meiotic chromosome behavior and capsule setting in Doritaenopsis hybrids. J. Amer. Soc. Hort. Sci. 133: 107-116

Chou, Y. M. 2013 Analyses of sporad types at different buds development stage and pollen DNA content in Phalaenopsis orchids. Master's thesis. National Chiayi Univ

Dewitte, A., Eeckhaut, T., J. Van Huylenbroeck and E. Van Bockstaele. 2010 Induction of $2 n$ pollen formation in Begonia by trifluralin and $\mathrm{N}_{2} \mathrm{O}$ treatments. Euphytica 171: 283-293

Grlesbach, R. J. 1985 Polyploidy in Phalaenopsis orchid improvement. J. Hered. 76: 74-75

Kitamura, S., M. Akutsu and K. Okazaki. 2009 Mechanism of action of nitrous oxide gas applied as a polyploidizing agent during meiosis in lily. Sex Plant Reprod. 22: 9-14

Li, Y. H., X.Y. Kang, S. D. Wang, Z. H. Zhang and H. W. Chen. 2008 Triploid induction in Populus alba $\times$ P. glandulosa by chro- mosome doubling of female gametes. Silvae Geneti. 57: 37-40

Lim, K. B., M. S. Ramanna, J. H. De Jong, E. Jacobsen and J. M. Van Tuyl. 2001 Indeterminate meiotic restitution (IMR)- a novel type of meiotic nuclear restitution mechanism detected in interspecific lily hybrids by GISH. Theor. Appl. Genet. 103: 219230

Okazaki, K., K. Kurimoto, I. Miyajima, A. Enami, H. Mizuochi, Y Matumoto and H. Ohya 2005 Induction of $2 n$ pollen in tulips by arresting the meiotic process with nitrous oxide gas. Euphytica 143: 101-114

Ramanna, M. S. and E. Jacobsen. 2003 Relevance of sexual polyploidization for crop improvement - A review. Euphytica 133: $3-18$

Sato, T., K. Miyoshi and K. Okazaki. 2010 Induction of $2 n$ gametes and $4 n$ embryo in Lilium (Lilium $\times$ formolongi Hort.) by nitrous oxide gas treatment. Acta Hort. 855: 243-248

Tang, C. Y. and W. H. Chen. 2007 Breeding and development of new varieties in Phalaenopsis. In: Chen W. H. and Chen H. H. (eds.), Orchid Biotechnology. pp. 1-22. World Scientific, New Jersy

Wongprichachan, P., T. M. Shen, K. L. Huang and H. Okubo. 2012 Meiotic behavior, capsule setting and seed germination of diploid and polyploidy Phalaenopsis amabilis. J. Fac. Agr. Kyushu Univ. 57: 405-409

Wongprichachan, P., K. L. Huang, Y. M. Chou, S. T. Hsu, T. Y. Liu and H. Okubo. 2013a Induction of unreduced gamete in Phalaenopsis by $\mathrm{N}_{2} \mathrm{O}$ treatments. J. Fac. Agr., Kyushu Univ. 58: $27-31$

Wongprichachan, P., K. L. Huang, S. T. Hsu, Y. M. Chou, T. Y. Liu and H. Okubo. 2013b Induction of polyploid Phalaenopsis by $\mathrm{N}_{2} \mathrm{O}$ treatments. J. Fac. Agr., Kyushu Univ. 58: 33-36

Wu, H., S. Zheng, Y. He, G. Yan, Y. Bi and Y. Zhu. 2007 Diploid female gametes induced by colchicines in oriental lilies. Sci. Hortic. 114: 50-53

Xiao, Y. Q., S. X. Zheng, C. L. Long, L. Zheng, W. L. Guan and Y. Zhao, 2007 Initial study on $2 n$-gametes induction of Strelitzia reginae. J. Yunnan Agr. Univ 22: 475-479

Zhong, C., S. N. Zhang, X. H. Yu, Y. Li, X. L. Hou and S. J. Li. 2010 Studies on the induction of $2 n$ gamete in Chinese cabbage and the production of tetraploid by sexual polyploidization. Acta Hort. Sinica 37: 1789-1795 